\title{
Relating Plant Architecture to Eggplant Fruit Quality
}

\author{
Brian A. Kahn ${ }^{1,2}$ \\ Department of Horticulture and Landscape Architecture, 358 Agricultural Hall, Oklahoma State \\ University, Stillwater, OK 74078-6027
}

AdDitional INDEX words. Solanum melongena, cultivars, fruiting planes, morphology

\begin{abstract}
A 2-year study was conducted at Bixby, OK, to examine shoot characteristics of several eggplant (Solanum melongena) cultivars, including the vertical distribution patterns of fruit production, and to examine possible relationships of these traits to aspects of fruit quality. Plants of 11 cultivars of purple-fruited eggplant were fieldgrown following local production practices. Fourteen harvests of fruit that had reached horticultural maturity were made from 99 plants in each year over a period of $\approx 45$ days per year. On each harvest date, every fruit that was harvested from an individual plant was charted. Before a fruit was severed from the plant, heights were measured from the soil surface to the pedicel attachment and to the blossom end. Each fruit was then weighed and categorized for marketability. On the day after the final harvest, each data plant was measured for height and diameter of the main stem and then severed at soil level for subsequent measurement of shoot dry weight. 'Classic', 'Dusky', 'Megal', and 'Santana' were the only cultivars that produced more than $50 \%$ marketable fruit in both years. There were no consistent relationships between plant height, stem diameter, or shoot dry weight and fruit quality. For a given cultivar, the fruiting plane was defined as the vertical space in which fruit were found over the course of the harvest period. This was delimited at the top by the mean height above the soil of the point of pedicel attachment and at the bottom by the mean height above the soil of the blossom end. The cultivars differed in fruiting planes, but height of fruit set was relatively unimportant as a determinant of overall fruit quality. Cull fruit usually had blossom ends that were higher off the ground than marketable fruit. The primary reason for cull fruit production was determined for two cultivars: 'Black Beauty' had poor fruit color and 'Black Bell' was relatively susceptible to fruit rot (primarily caused by Phomopsis vexans). Fruit scarring was found to be a major contributor to cull fruit production. Cultivars differed in fruit scarring in 1 of 2 years, and there was evidence that scarred fruit occurred higher in the crop canopy than marketable fruit.
\end{abstract}

The effects of crop canopy architecture on fruit quality have been studied primarily in tree fruit crops such as apple [Malus domestica (Fouché et al., 2010; González-Talice et al., 2013)] and mango [Mangifera indica (Normand et al., 2009)]. Vertical distribution patterns of fruit production in the crop canopy have been reported for some vegetables such as common bean [Phaseolus vulgaris (DeMoura and Foster, 1986)], cowpea [Vigna unguiculata (Kahn and Stoffella, 1989)], and bell pepper [Capsicum annuum (Gaye et al., 1992)]. Some vegetative traits have been used to characterize eggplant accessions in the European Eggplant Genetic Resources Network (EGGNET) database, including plant height, plant growth habit, and number of leaves to first flower (Prohens et al., 2005). However, the spatial distribution of fruit yield within the shoots of eggplant has received little attention. Information on plant architecture is useful in developing simulation models of crop growth (Barthélémy and Caraglio, 2007) and can assist plant breeders who are seeking to increase yield (Adams, 1982; Gaye et al., 1992). Such information can also provide a better understanding of factors affecting fruit marketability. For example, Ando and Grumet (2006) concluded that plant architecture

Received for publication 30 July 2013. Accepted for publication 19 Sept. 2013. Approved for publication by the Director, Oklahoma Agricultural Experiment Station. This research was supported in part under project $\mathrm{H}-2026$.

The information given in this publication is for educational purposes only. Mention of a trademark, proprietary product, or vendor does not constitute a guarantee or warranty of the product nor does it imply approval or disapproval to the exclusion of other products or vendors that may also be suitable.

${ }^{1}$ Professor.

${ }^{2}$ Corresponding author. E-mail: brian.kahn@okstate.edu. that reduces contact of fruit with the soil could be useful for control of Phytophthora capsici in cucumber (Cucumis sativus). If it were to be shown that proximity to the soil was detrimental to eggplant fruit quality, then there would be more justification for staking and trellising, which are costly, labor-intensive practices. The purpose of these studies was to describe the vertical distribution patterns of fruit production, or "fruiting planes," in several eggplant cultivars and to examine possible relationships of these patterns to aspects of fruit quality. Three other shoot characteristics related to plant architecture (plant height, stem diameter, and shoot dry weight) also were examined for possible relationships to fruit quality.

\section{Materials and Methods}

A 2-year study was conducted. Plots were located at the Oklahoma Vegetable Research Station in Bixby on a Severn very fine sandy loam [coarse-silty, mixed (calcareous), thermic Typic Udifluvent]. The soil was prepared with a preplantincorporated application of urea to supply nitrogen at $56 \mathrm{~kg} \cdot \mathrm{ha}^{-1}$ and of napropamide for weed control at $1.4 \mathrm{~kg} \cdot \mathrm{ha}^{-1}$ in both years. Neither raised beds nor plastic mulches were used per local production practices.

Eleven eggplant cultivars varying in fruit size but roughly conforming to a common elongated teardrop shape and with concolor, dark purple-black skins were chosen for this work. All except 'Black Beauty' were commercial $F_{1}$ hybrids. Seeds were sown in peat-lite mix in flats with 128 inverted pyramid cells per flat in a greenhouse on 17 Mar. 2005 and 24 Mar. 2006. Ten (2005) or nine (2006) plants of a given cultivar per plot 
were transplanted to the field on 25 Apr. 2005 and 28 Apr. 2006 with $60 \mathrm{~cm}$ between plants within rows and $1.8 \mathrm{~m}$ between rows. A completely randomized design with three replications was used in both years. Transplants each received $\approx 200 \mathrm{~mL}$ of starter solution providing $1079 \mathrm{mg} \cdot \mathrm{L}^{-1}$ nitrogen $(\mathrm{N}), 941 \mathrm{mg} \cdot \mathrm{L}^{-1}$ phosphorus, $895 \mathrm{mg} \cdot \mathrm{L}^{-1}$ potassium, plus $300 \mathrm{mg} \cdot \mathrm{L}^{-1}$ diazinon for soil insect control. Surface drip irrigation was installed to supplement natural rainfall in both years.

Plants received a sidedress application of urea to supply $\mathrm{N}$ at $56 \mathrm{~kg} \cdot \mathrm{ha}^{-1}$ on 7 June 2005 and 5 June 2006. Three foliar insecticides were applied for insect control: permethrin $\left(224 \mathrm{~g} \cdot \mathrm{ha}^{-1}\right.$ on 3 June 2005, 6 July 2005, 13 July 2005, and 18 May 2006), esfenvalerate ( $34 \mathrm{~g} \cdot \mathrm{ha}^{-1}$ on 27 June 2005,5 June 2006,3 July 2006, 17 July 2006, and 3 Aug. 2006), and methomyl (560 g.ha ${ }^{-1}$ on 19 June and 24 July 2006). Three foliar fungicides were used for disease control: azoxystrobin ( $200 \mathrm{~g} \cdot \mathrm{ha}^{-1}$ on 13 July 2005 and $112 \mathrm{~g} \cdot \mathrm{ha}^{-1}$ on 3 and 17 July 2006), chlorothalonil (1169 g.ha ${ }^{-1}$ on 27 July 2005), and copper hydroxide (1726 g.ha ${ }^{-1} 24$ July and 3 Aug. 2006).

Fourteen harvests of fruit that had reached horticultural maturity were made each year. Harvests began on 20 June 2005 and 22 June 2006 and continued twice per week through 4 Aug. 2005 and 7 Aug. 2006. Data were taken from three individual plants per plot; thus, with 11 cultivars and three replications,

Table 1. Yields from 11 field-grown eggplant cultivars at Bixby, OK, in 2005. ${ }^{\mathrm{z}}$

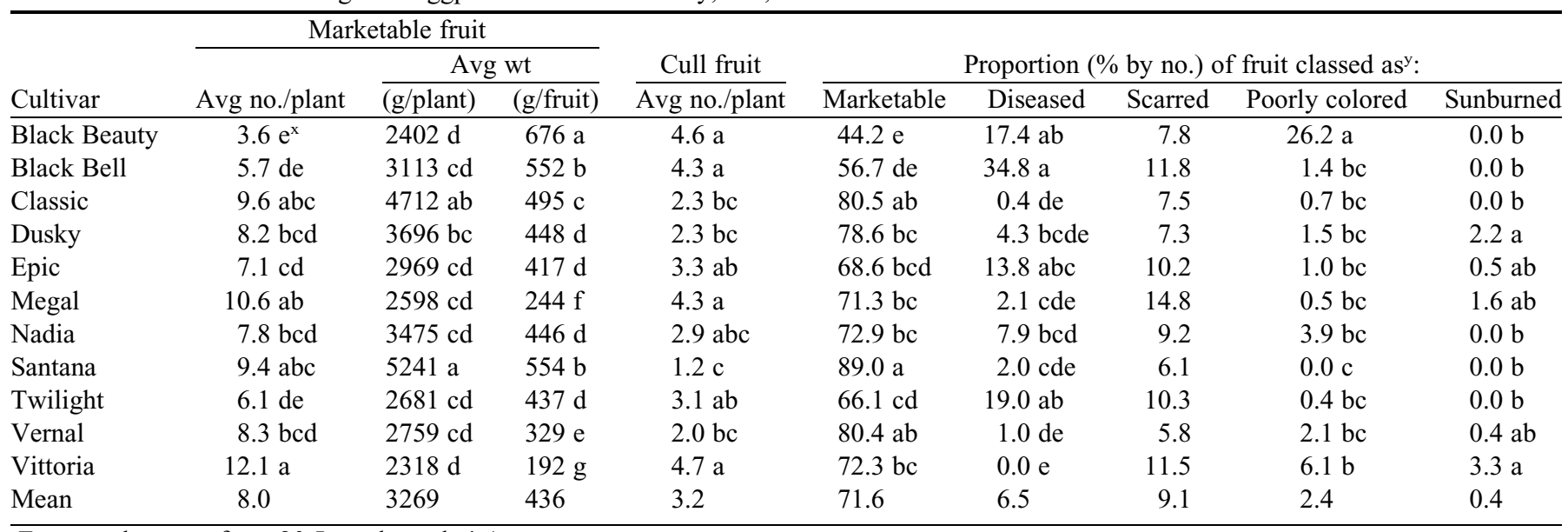

${ }^{\mathrm{z}}$ Fourteen harvests from 20 June through 4 Aug.

${ }^{y}$ Arcsine transformation was applied to the original data before analysis. Back-transformed means are shown. Percentages may not add to 100 because data are not reported for misshapen fruit or those culled for insect injury (these defects were minor contributors to overall cull fruit production and cultivars did not show differences). Also, some fruit exhibited multiple defects.

${ }^{x}$ Mean separation in columns by Duncan's multiple range test, $P \leq 0.05$. Letters are shown only if the F-test for main effect of cultivar is significant, $P \leq 0.05$.

Table 2. Yields from 11 field-grown eggplant cultivars at Bixby, OK, in $2006 .^{\mathrm{z}}$

\begin{tabular}{|c|c|c|c|c|c|c|c|c|c|}
\hline \multirow[b]{3}{*}{ Cultivar } & \multicolumn{3}{|c|}{ Marketable fruit } & \multirow{3}{*}{$\frac{\text { Cull fruit }}{\text { Avg no./plant }}$} & \multirow{2}{*}{\multicolumn{5}{|c|}{ Proportion ( $\%$ by no.) of fruit classed $a^{\mathrm{y}}$ : }} \\
\hline & \multirow[b]{2}{*}{ Avg no./plant } & \multicolumn{2}{|c|}{ Avg wt } & & & & & & \\
\hline & & (g/plant) & (g/fruit) & & Marketable & Diseased & Scarred & Poorly colored & Sunburned \\
\hline Black Beauty & $1.4 \mathrm{e}^{\mathrm{x}}$ & $727 \mathrm{~d}$ & $482 \mathrm{a}$ & $4.1 \mathrm{cdef}$ & $25.1 \mathrm{~d}$ & 21.2 & $9.3 \mathrm{e}$ & $45.5 \mathrm{a}$ & 0.0 \\
\hline Classic & $5.2 \mathrm{ab}$ & $2217 \mathrm{ab}$ & $422 \mathrm{~b}$ & $3.4 \mathrm{def}$ & $60.2 \mathrm{ab}$ & 5.8 & 20.1 cde & $3.4 \mathrm{bc}$ & 0.6 \\
\hline Dusky & $3.7 \mathrm{bcd}$ & $1190 \mathrm{~cd}$ & $323 \mathrm{~d}$ & 3.0 ef & $55.1 \mathrm{abc}$ & 8.6 & $28.5 \mathrm{abc}$ & $1.6 \mathrm{bc}$ & 0.8 \\
\hline Epic & $4.0 \mathrm{bcd}$ & $1353 \mathrm{~cd}$ & $335 \mathrm{~d}$ & 5.6 bcde & $42.4 \mathrm{bcd}$ & 12.3 & $37.5 \mathrm{ab}$ & $0.0 \mathrm{c}$ & 2.2 \\
\hline Nadia & $3.3 \mathrm{~cd}$ & $1320 \mathrm{~cd}$ & $393 \mathrm{bc}$ & $4.6 \mathrm{cdef}$ & $41.9 \mathrm{bcd}$ & 13.3 & $38.6 \mathrm{ab}$ & $0.0 \mathrm{c}$ & 0.0 \\
\hline Santana & $5.1 \mathrm{abc}$ & $2490 \mathrm{a}$ & $486 \mathrm{a}$ & $2.1 \mathrm{f}$ & $72.0 \mathrm{a}$ & 1.1 & $13.3 \mathrm{de}$ & $3.0 \mathrm{bc}$ & 4.1 \\
\hline Twilight & $4.4 \mathrm{bc}$ & $1555 \mathrm{bc}$ & $349 \mathrm{~cd}$ & $7.3 \mathrm{ab}$ & $38.3 \mathrm{~cd}$ & 10.7 & $39.6 \mathrm{ab}$ & $2.8 \mathrm{bc}$ & 0.4 \\
\hline Vernal & $3.4 \mathrm{bcd}$ & $1079 \mathrm{~cd}$ & $312 \mathrm{~d}$ & $5.7 \mathrm{bcd}$ & $37.3 \mathrm{~cd}$ & 6.0 & $44.2 \mathrm{a}$ & $4.7 \mathrm{bc}$ & 4.7 \\
\hline Vittoria & $6.4 \mathrm{a}$ & $1247 \mathrm{~cd}$ & $193 \mathrm{e}$ & $9.1 \mathrm{a}$ & $41.5 \mathrm{bcd}$ & 2.8 & $36.0 \mathrm{ab}$ & $10.5 \mathrm{~b}$ & 5.7 \\
\hline Mean & 4.1 & 1403 & 360 & 5.1 & 45.1 & 9.5 & 28.8 & 4.9 & 1.4 \\
\hline
\end{tabular}

${ }^{\mathrm{z}}$ Fourteen harvests from 22 June through 7 Aug.

${ }^{y}$ Arcsine transformation was applied to the original data before analysis. Back-transformed means are shown. Percentages may not add to 100 because data are not reported for misshapen fruit or those culled for insect injury (these defects were minor contributors to overall cull fruit production and cultivars did not show differences). Also, some fruit exhibited multiple defects.

${ }^{x}$ Mean separation in columns by Duncan's multiple range test, $P \leq 0.05$. Letters are shown only if the F-test for main effect of cultivar is significant, $P \leq 0.05$. 
there were 99 experimental units in each year. On each harvest date, every fruit that was harvested from an individual plant was charted. Before a fruit was severed from the plant with hand shears, heights were measured from the soil surface to the pedicel attachment and to the blossom end. Each fruit then was weighed and categorized for marketability. Reasons for culling included 1) disease (the primary causal agent was confirmed by laboratory diagnosis as Phomopsis vexans); 2) scarring (typically vertical striations, but sometimes also brown, scab-like lesions or a "blossom tear" extending from the blossom end up the side of a fruit); 3) poor coloration (in contrast to the desired uniform purple-black, including both pale fruit and those that developed a reddish brown pigmentation); 4) sunburn; 5) insect injury; or 6) misshapen fruit. Most fruit were culled as a result of one primary defect, but multiple defects were noted when present.

Each year, on the day after the final harvest, each data plant was measured for height from the soil surface to the highest growing point. Next, a digital caliper was used to measure the stem diameter at soil level. Finally, each plant was cut at soil level and placed in a burlap sack after any remaining fruit were removed and discarded. Plants were dried at $51{ }^{\circ} \mathrm{C}$ for $9 \mathrm{~d}$ and shoot dry weights were recorded.

Data were evaluated by year with analysis of variance procedures generated using SAS/STAT software (Version 9.3 for Windows; SAS Institute, Cary, NC). An arcsine transformation was applied to percentage data before analysis, and back-transformed means were reported. If the main effect of cultivar was significant $(P \leq 0.05)$, means were separated by Duncan's multiple range test. Correlation coefficients $(r)$ also were calculated for selected variables.

\section{Results and Discussion}

Cultivars varied in yield in both years, as would be expected (Tables 1 and 2). The two cultivars with the smallest individual fruit ('Megal' and 'Vittoria') tended to have the most marketable fruit per plant. However, they did not differ in marketable fruit number from two other cultivars ('Classic' and 'Santana') with relatively large individual fruit. Overall, 'Santana' produced the numerically greatest weight of marketable fruit per plant in both years and was statistically similar only to 'Classic.' 'Classic', 'Dusky', 'Megal', and 'Santana' were the only cultivars that produced more than $50 \%$ marketable fruit in both years. 'Vittoria' was the numerical leader in cull fruit production in both years, but otherwise cultivar rankings for cull fruit were not particularly consistent. 'Black Beauty', the only open-pollinated cultivar in the study, produced less than $50 \%$ marketable fruit in both years.

Cultivars averaged $71.6 \%$ marketable fruit in 2005 but only $45.1 \%$ marketable fruit in 2006 (Tables 1 and 2). Plants were under more environmental stresses in 2006 than in 2005. Air
Table 4. Correlation analyses for eggplant shoot characteristics with marketable (mkt) fruit yield.

\begin{tabular}{|c|c|c|c|c|c|c|}
\hline & Yr & $\begin{array}{c}\text { Plant } \\
h t^{z}\end{array}$ & Dry wt & $\begin{array}{c}\text { Stem } \\
\text { diam }^{y}\end{array}$ & $\begin{array}{c}\text { Mkt fruit } \\
\text { no. per } \\
\text { plant }\end{array}$ & $\begin{array}{c}\text { Mkt fruit } \\
\text { wt per } \\
\text { plant }\end{array}$ \\
\hline \multirow[t]{2}{*}{ Plant ht } & 2005 & & $0.244 \mathrm{NS}$ & $0.459 * *$ & $0.330 \mathrm{NS}$ & $0.263 \mathrm{NS}$ \\
\hline & 2006 & & $0.262 \mathrm{NS}$ & $0.185 \mathrm{NS}$ & $0.447 * *$ & $0.170 \mathrm{NS}$ \\
\hline \multirow[t]{2}{*}{ Dry wt } & 2005 & & & $0.823 * *$ & $-0.253 \mathrm{NS}$ & $0.502 * *$ \\
\hline & 2006 & & & $0.726 * *$ & $-0.007 \mathrm{NS}$ & $0.315 \mathrm{NS}$ \\
\hline \multirow[t]{2}{*}{ Stem diam } & 2005 & & & & $-0.062 \mathrm{NS}$ & $0.399 *$ \\
\hline & 2006 & & & & $-0.062 \mathrm{NS}$ & $0.331 \mathrm{NS}$ \\
\hline \multirow{2}{*}{$\begin{array}{c}\text { Mkt fruit no. } \\
\text { per plant }\end{array}$} & 2005 & & & & & $0.386 *$ \\
\hline & 2006 & & & & & $0.651 * *$ \\
\hline
\end{tabular}

${ }^{\mathrm{z}}$ Height measured from soil to highest growing point.

${ }^{\mathrm{y}}$ Stem diameter measured on main stem at soil level (before drying). Ns, ${ }^{*}, * *$ Nonsignificant or significant at $P \leq 0.05$ or 0.01 , respectively.

temperature and relative humidity $(\mathrm{RH})$ during the 2005 harvest period averaged $26.8^{\circ} \mathrm{C}$ and $68.5 \% \mathrm{RH}$ compared with $28.0^{\circ} \mathrm{C}$ and $58.6 \% \mathrm{RH}$ during the 2006 harvest period. The primary fruit disorder in both years was scarring. In 2005, fewer than $10 \%$ of fruit were scarred and cultivars did not differ in this defect. In contrast, scarring affected more than $25 \%$ of fruit in 2006 and cultivars showed differences in susceptibility. Pepper cultivars also have been reported to differ in fruit scarring (Johnson and Knavel, 1990).

Cultivars showed wide differences in disease susceptibility in both years (Tables 1 and 2); however, the CV was high (57.1) in 2006 and statistical differences could not be shown. 'Black Bell' averaged at least 30\% infected fruit in both years. 'Black Beauty' exceeded all other cultivars in the defect of poor fruit color in both years, and it was the primary reason for cull production in this cultivar. 'Black Beauty' fruit often had irregular or pale skin color. Variations in intensity of purple coloration were reported among fruits of 'Black Queen', a local strain of 'Black Beauty', by Nothmann et al. (1976). 'Vittoria' had the numerically highest number of sunburned fruit in both years, but sunburn was a relatively minor contributor 
to overall cull fruit production. Data are not reported for misshapen fruit or those culled for insect injury, because these defects were minor contributors to overall cull fruit production and cultivars did not show differences.

Cultivars varied in shoot characteristics in both years (Table 3), but there were no clear connections between the measured shoot variables and fruit quality. For example, 'Megal' had the numerically tallest plants in both years and the statistically tallest plants in 2006. However, it was statistically similar to several other cultivars for total marketable and total cull fruit production (Tables 1 and 2). Correlation analyses (Table 4) confirmed the lack of consistent relationships between measured shoot variables and marketable fruit production. Illangakoon et al. (2004) studied six eggplant cultivars and reported plant dry weight at the eighth harvest was not correlated with fruit number per plant and only weakly correlated $(r=0.46)$ with fruit weight per plant.

For a given cultivar, the fruiting plane was defined as the vertical space in which fruit were found over the course of the harvest period. This was delimited at the top by the mean height above the soil of the point of pedicel attachment and at the bottom by the mean height above the soil of the blossom end. Fruiting planes of individual cultivars varied from year to year (Table 5). However, there were no consistent relationships between fruiting plane and fruit quality. The cultivars that were numerically highest ('Vittoria') and lowest ('Black Beauty') in both years for marketable fruit number per plant (Tables 1 and 2) had statistically similar heights to pedicel attachment and heights to blossom end in both years (Table 5). The cultivars with the lowest ('Dusky') and highest ('Megal') overall fruiting plane (Table 5) in both years did not differ for marketable fruit number per plant in both years (Tables 1 and 2) or for cull fruit number per plant in 2006 (Table 2).

One might expect the fruiting planes to rise as harvest progressed and plants became taller. This was seen as an overall trend, but the response was not strongly linear. Correlations $(r)$ between position in the fruit harvesting sequence (position $1=$ first fruit harvested from a given plant) and height to pedicel attachment were 0.53 in 2005 and 0.47 in 2006 (both significant at $P \leq 0.01$ ). Thus, fruit with a later harvest position were not necessarily higher in the plant canopy than those harvested earlier, likely as a result of fruit weighing down plant branches. An example is shown in Figure 1 for 'Classic' in 2005.

In addition to main effects of cultivar, three specific analyses were performed to examine possible effects of height to pedicel attachment and height to blossom end on total cull fruit production, diseased fruit production, and scarred fruit production as well as cultivar $\times$ fruit grade interactions (Table 6). Height to pedicel attachment was not a factor in total cull or diseased fruit production, indicating that height of fruit set was relatively unimportant as a determinant of fruit marketability. However, there was a consistent trend for scarred fruit to have been set higher than marketable fruit (significant in 2006). Total cull fruit, diseased fruit (2006 only), and scarred fruit all had blossom ends that were higher off the ground than marketable fruit (Table 6). A partial explanation for this finding is that diseased fruit sometimes deteriorated before reaching full size. However, it seems clear that proximity to the soil surface was not in itself detrimental to fruit quality. No significant cultivar $\times$ fruit grade interactions were evident (Table 6).

This study showed that eggplant cultivars differed in fruiting planes. However, fruiting plane and other measured plant architectural variables did not consistently affect fruit quality. The primary reason for cull fruit production was determined for two cultivars: 'Black Beauty' had poor fruit color, and 'Black

Table 5. Fruiting planes for 11 field-grown eggplant cultivars at Bixby, $\mathrm{OK}$, in 2005 and $2006 .^{\mathrm{z}}$

\begin{tabular}{lllllc}
\hline & \multicolumn{2}{c}{2005} & & \multicolumn{2}{c}{2006} \\
\cline { 2 - 3 } \cline { 5 - 6 } Cultivar & $\begin{array}{c}\text { Ht to pedicel } \\
\text { attachment } \\
(\mathrm{cm})\end{array}$ & $\begin{array}{c}\text { Ht to } \\
\text { blossom } \\
\text { end }(\mathrm{cm})\end{array}$ & $\begin{array}{c}\text { Ht to pedicel } \\
\text { attachment } \\
(\mathrm{cm})\end{array}$ & $\begin{array}{c}\text { Ht to } \\
\text { blossom } \\
\text { end }(\mathrm{cm})\end{array}$ \\
\hline Black Beauty & $24 \mathrm{def}^{\mathrm{y}}$ & $4 \mathrm{bcd}$ & & $21 \mathrm{ef}$ & $4 \mathrm{~cd}$ \\
Black Bell & $22 \mathrm{ef}$ & $2 \mathrm{~cd}$ & & $21 \mathrm{ef}$ & $2 \mathrm{~d}$ \\
Classic & $28 \mathrm{abc}$ & $6 \mathrm{abc}$ & & $23 \mathrm{cdef}$ & $3 \mathrm{~d}$ \\
Dusky & $21 \mathrm{f}$ & $1 \mathrm{~d}$ & & $20 \mathrm{f}$ & $2 \mathrm{~d}$ \\
Epic & $26 \mathrm{abcde}$ & $6 \mathrm{abc}$ & & $24 \mathrm{cdef}$ & $5 \mathrm{bcd}$ \\
Megal & $30 \mathrm{a}$ & $9 \mathrm{a}$ & & $32 \mathrm{a}$ & $11 \mathrm{a}$ \\
Nadia & $29 \mathrm{ab}$ & $7 \mathrm{ab}$ & & $27 \mathrm{bc}$ & $5 \mathrm{bcd}$ \\
Santana & $27 \mathrm{abcd}$ & $4 \mathrm{bcd}$ & & $28 \mathrm{ab}$ & $8 \mathrm{ab}$ \\
Twilight & $25 \mathrm{cde}$ & $4 \mathrm{bcd}$ & & $22 \mathrm{def}$ & $4 \mathrm{~cd}$ \\
Vernal & $25 \mathrm{bcde}$ & $6 \mathrm{abc}$ & & $26 \mathrm{bcd}$ & $6 \mathrm{bc}$ \\
Vittoria & $26 \mathrm{abcde}$ & $5 \mathrm{abcd}$ & & $25 \mathrm{bcde}$ & $4 \mathrm{~cd}$ \\
Mean & 26 & 5 & & 24 & 5
\end{tabular}

${ }^{\mathrm{z}}$ For a given cultivar, the fruiting plane was defined as the vertical space in which fruit were found over the course of the harvest period. This was delimited at the top by the mean height above the soil of the point of pedicel attachment and at the bottom by the mean height above the soil of the blossom end.

${ }^{y}$ Mean separation in columns by Duncan's multiple range test, $P \leq$ 0.05 .

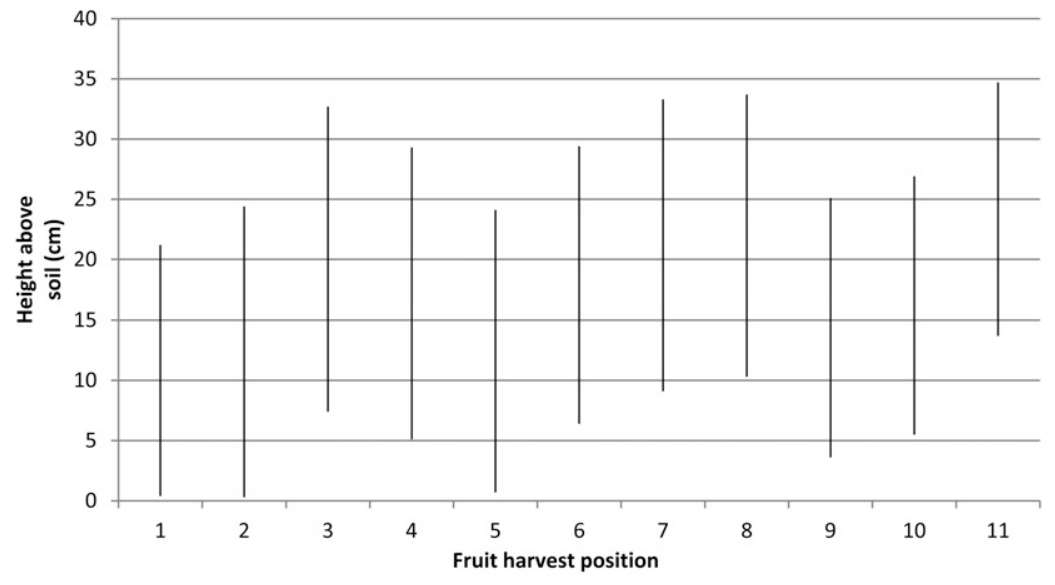

Fig. 1. Fruiting planes across harvests for 'Classic' eggplant in 2005. A vertical bar represents a mean fruiting plane for a given position in the fruit harvesting sequence (position $1=$ first fruit harvested from a given plant, $\mathrm{N}=$ nine plants). This cultivar averaged 11 fruit per plant in 2005 . The fruiting plane was defined as the vertical space in which fruit were found over the course of the harvest period. This was delimited at the top by the mean height above the soil of the point of pedicel attachment (top of each vertical bar) and at the bottom by the mean height above the soil of the blossom end (bottom of each vertical bar). 
Table 6. Comparisons of height from soil to pedicel attachment and from soil to blossom end of eggplant fruit harvested at Bixby, OK, in 2005 and 2006 as related to fruit marketability. ${ }^{\mathrm{z}}$

\begin{tabular}{|c|c|c|c|c|}
\hline \multirow[b]{2}{*}{ Fruit grade } & \multicolumn{2}{|c|}{2005} & \multicolumn{2}{|c|}{2006} \\
\hline & $\begin{array}{c}\text { Ht to } \\
\text { pedicel } \\
\text { attachment } \\
(\mathrm{cm})\end{array}$ & $\begin{array}{c}\text { Ht to } \\
\text { blossom } \\
\text { end }(\mathrm{cm})\end{array}$ & $\begin{array}{c}\text { Ht to } \\
\text { pedicel } \\
\text { attachment } \\
(\mathrm{cm})\end{array}$ & $\begin{array}{c}\text { Ht to } \\
\text { blossom } \\
\text { end }(\mathrm{cm})\end{array}$ \\
\hline Marketable (mkt) & 26 & 4 & 24 & 4 \\
\hline Cull for any reason & 26 & 6 & 25 & 6 \\
\hline Cultivar & $* *$ & $*$ & $* *$ & $* *$ \\
\hline Mkt vs. cull & NS & $*$ & NS & $* *$ \\
\hline Interaction & NS & NS & NS & NS \\
\hline Marketable & 25 & 4 & 24 & 4 \\
\hline Diseased & 24 & 4 & 24 & 5 \\
\hline Cultivar $^{z}$ & $* *$ & NS & $* *$ & $* *$ \\
\hline Mkt vs. diseased & NS & NS & NS & $*$ \\
\hline Interaction & NS & NS & NS & NS \\
\hline Marketable & 26 & 4 & 24 & 4 \\
\hline Scarred & 28 & 8 & 26 & 7 \\
\hline Cultivar & $* *$ & $* *$ & $* *$ & $* *$ \\
\hline Mkt vs. scarred & NS & $* *$ & $*$ & $* *$ \\
\hline Interaction & NS & NS & NS & NS \\
\hline
\end{tabular}

${ }^{\mathrm{z}}$ Comparisons are between mean values for marketable fruit and those culled for specified reasons across 11 cultivars per year. Exception: The cultivars Classic, Dusky, Megal, Santana, Vernal, and Vittoria (2005) and Santana (2006) were excluded from the analyses for marketable vs. diseased fruit as a result of low numbers of diseased fruit. Cultivar $\times$ fruit grade interactions also were tested and results are presented here.

NS, ${ }^{*}$,* Nonsignificant or significant at $P \leq 0.05$ or 0.01 , respectively.

Bell' was relatively susceptible to fruit rot. Fruit scarring was found to be a major contributor to cull fruit production. Cultivars differed in fruit scarring in 1 of 2 years, and there was evidence that scarred fruit occurred higher in the crop canopy than marketable fruit. Although scarred fruit usually remained suitable for consumption, their appearance rendered them unmarketable; thus, this is an economic concern. More research is needed into the occurrence of scarred fruit in fieldgrown eggplant.

\section{Literature Cited}

Adams, M.W. 1982. Plant architecture and yield breeding. Iowa State J. Res. 56:225-254.

Ando, K. and R. Grumet. 2006. Evaluation of altered cucumber plant architecture as a means to reduce Phytophthora capsici disease incidence on cucumber fruit. J. Amer. Soc. Hort. Sci. 131:491-498.

Barthélémy, D. and Y. Caraglio. 2007. Plant architecture: A dynamic, multilevel and comprehensive approach to plant form, structure and ontogeny. Ann. Bot. (Lond.) 99:375-407.

DeMoura, R.L. and K.W. Foster. 1986. Spatial distribution of seed yield within plants of bean. Crop Sci. 26:337-341.

Fouché, J.R., S.C. Roberts, S.J.E. Midgley, and W.J. Steyn. 2010. Peel color and blemishes in 'Granny Smith' apples in relation to canopy light environment. HortScience 45:899-905.

Gaye, M.M., G.W. Eaton, and P.A. Joliffe. 1992. Rowcovers and plant architecture influence development and spatial distribution of bell pepper fruit. HortScience 27:397-399.

González-Talice, J., J.A. Yuri, and A. del Pozo. 2013. Relations among pigments, color and phenolic concentrations in the peel of two Gala apple strains according to canopy position and light environment. Sci. Hort. 151:83-89.

Illangakoon, T.K., D.C. Bandara, and H. Fonseka. 2004. Evaluation of physio-agronomic and chemical traits in relation to the productivity of eggplant (Solanum melongena L.). Trop. Agr. Res. 16:14-24.

Johnson, D. and D.E. Knavel. 1990. Inheritance of cracking and scarring in pepper fruit. J. Amer. Soc. Hort. Sci. 115:172-175.

Kahn, B.A. and P.J. Stoffella. 1989. Distribution pattern of seed yield in cowpea. Crop Sci. 29:981-984.

Normand, F., A.K.P. Bello, C. Trottier, and P.E. Lauri. 2009. Is axis position within tree architecture a determinant of axis morphology, branching, flowering and fruiting? An essay in mango. Ann. Bot. (Lond.) 103:1325-1336.

Nothmann, J., I. Rylski, and M. Spigelman. 1976. Color and variations in color intensity of fruit of eggplant cultivars. Sci. Hort. 4:191-197.

Prohens, J., J.M. Blanca, and F. Nuez. 2005. Morphological and molecular variation in a collection of eggplants from a secondary center of diversity: Implications for conservation and breeding. J. Amer. Soc. Hort. Sci. 130:54-63. 